[Duncan, J., \& Rowe, L. (1997). Don't Be Too Polite Girls, Don't Be Too Polite: Kindergarten Teachers and Employment Contracts. New Zealand Annual Review of Education, 6, 157-179]

\section{Don't Be Too Polite Girls, Don't Be Too Polite: Kindergarten Teachers and Employment Contracts}

\author{
JUDITH DUNCAN AND LEE ROWE
}

\section{Abstract:}

Kindergarten teachers have experienced significant changes in their employment contracts since 1992. In 1996 the New Zealand political environment of an upcoming MMP election combined with the issues of women, women's work and the discourses relating to kindergarten teaching and teachers. The outcome of this combination was a regaining of some previously lost employment conditions, as well as improvements "against the odds". This article discusses the historical struggle for employment conditions in the kindergarten service and the events of the 1996 employment negotiations.

Don't be too polite girls, don't be too polite

Show a little fight girls, show a little fight

Don't be fearful of offending, in case you get the sack

Just recognise your value and we won't look back. ${ }^{1}$

\section{The Gendered History and Background of Kindergarten Teaching}

Kindergarten teachers, along with all workers in the early childhood service, have been paid less, historically and currently, than other teachers within the education service. In an earlier paper, Duncan (1996) has argued that kindergarten teaching, as a form of employment, has been positioned by two factors: firstly, its strong links with small children, which have often led it to be viewed as "caring", rather than "educating"; and secondly, the distinctive nature and issues surrounding a predominantly women-based profession. As the Ministry of Education stated:

\section{Judith Duncan and Lee Rowe}

The early childhood sector is staffed almost entirely by women. The concern with these teachers is not their low status relative to male early childhood teachers but the low status of early childhood teachers as a whole compared with teachers in other sectors and with similarly qualified employees in other sectors of the economy. (Ministry of Education, 1992, p. 13)

In 1990, permanent full-time teachers in kindergartens received only 73 percent of the salary of all other full-time teachers in the rest of the education sector (Dunn et al., 1992, p. 35). Thus, even after averaging for age differentials between the services, kindergarten salaries "still lagged some 13\% behind other teachers' salaries" (Dunn et al., 1992, p. 35). Many writers have discussed the perceived link between kindergarten teaching and "mothering". Work with young children is seen as "mothering and caring" (Cook, 1983, p. 15), that is, fulfilling the emotional, custodial and emotional needs of the child, rather than as the "presumed intellectual functions of the rest of the system" (Cook, 1983, p. 15). Writers have argued that while kindergarten teachers are seen to be doing the same work which women voluntarily do in the home and in the community, often for no monetary remuneration, it is difficult for teachers to argue for payment for worth (Cook, 1983; Cook, 1985; May, 1985; May, 1993b).

It has been argued that the engendered nature of kindergarten teaching has some inbuilt contradictions for teachers (Duncan, 1994a; Duncan, 1994b; Duncan, 1996). On the one hand kindergarten teaching celebrates women's work, promoting its importance and thus challenging and contesting its demotion and trivialising by dominant voices in society. But at the same time its gender-specific nature can place teachers in a powerless position for negotiating wages and working conditions. Women still bear the greatest responsibility in our society for wider family and care commitments, whether these be to partners, children or elderly relatives. The labour market choices they can make are correspondingly limited. This has been traced in studies examining women's career progressions and advancements (Apple, 1986; Casey \& Apple, 1989), and becomes problematicin a labour market system "where individual self-interest is elevated to the level that is in the Employment Contracts Act" (Sayers, 1992, p. 234).

Similarly, the government's social and fiscal agendas for education, combined with the labour reforms such as the Employment Contracts Act, have continued to play a large role in the employment lives and 
positions of kindergarten teachers. Teachers require supportive employment conditions to maintain quality provision in early childhood settings (Mitchell, 1996). However, early childhood facilities, constrained by lack of funding and regulations, "have not had a good record in upholding and imposing quality standards" (May, 1992, p. 89). Mitchell (1996) argues that appropriate government funding and a supportive state infra-structure is essential for this quality (Mitchell, 1996). These writers argue that these conditions have not occurred in New Zealand. Since 1990 government polices in the early childhood sector have reflected, what writers have called, an increasing agenda towards privatisation of the sector (Mitchell, 1996; Wells, 1991). This move can be seen in a variety of legislative changes. The most significant of these, in terms of kindergarten teachers' employment, have been the removal and re-instating of compulsory teacher registration for all teachers in state and integrated schools, and kindergartens (1996); the introduction of bulkfunding as a mechanism to reduce government expenditure and responsibility for directly paying teacher salaries (1992); and the State Services Commission's ability to delegate employment-negotiating responsibilities to local kindergarten employers (1991).

It has been argued that bulk funding of the early childhood sector has become a key lever for fiscal restraint for kindergarten employers, who have been facing the reality of impending funding shortfalls (Wylie, 1992). The State Services Commission also maintains its discretionary rights to veto any settlement it may not agree with. So despite having devolved responsibility to the kindergarten associations over wage negotiating, the Commission remains a pivotal force in the processes ensuring that employers do not exceed the budget constraints that the Ministers of Education and State Services are expecting.

Simpson (1993) describes how wages in the public service sector have historically and continually been used as "a political and fiscal instrument for dealing with deficits in the public accounts" (Simpson, 1993, p. 144). A combination of bulk funding, the Employment Contracts Act, and devolved management structures are not only the recipe for fiscal restraint in the kindergarten service, but also the opportunity for the government to withdraw from direct accountability for the kindergarten teaching service (Wells, 1991, p. 123).

Through this devolution of management of the kindergarten service and employment-negotiating responsibilities, a whole new relationship between teachers and association representatives has begun. While consistent with the general thrust of government reform, this has presented a new perspective for those within the kindergarten service, who, rather than dealing in a competitive labour market with their employers, have enjoyed a co-operative partnership in the past.

Behind all these changes has been the labour market philosophy of a "new right" agenda, which has significantly influenced all political activity over the last six years in which the National Government has been in office. Writers have expressed concern at the new right stance in early childhood, allowing market forces to dictate provision and standards (Lauder et al., 1988; May, 1990; May, 1992; Dalli and Meade, 1991). Duncan (1994a) claims that policies which derive from these philosophies (such as maximising choice and competition), when applied in the early childhood market, have the effect of driving down costs of the service (particularly to the government). At the same time, these policies call into question the provisions for quality control and standards for the safety of children, and the need for realistic working conditions for the teachers and workers (Duncan, 1994a).

The agendas of consecutive new right governments have set a powerful context for the kindergarten service and the teachers within the service. The emphasis on competitive individualism (Peter and Marshall, 1990, p. 176) is incompatible with a kindergarten service which has always worked on co-operative management, team work and power sharing. Trying to separate providers from consumers, teachers from employers, or teachers from parents and children, is undesirable and unworkable in a service where these people are often one and the same (Lauder, et al, 1988:26; Lauder, 1991, p. 13). Likewise, the co-operative nature of early childhood education has always been its greatest strength; "it is precisely the activity of community struggle and co-operation which provides the gain of social solidarity and the long-term stability of communities"' (Lauder, et al., 1988, p. 26).

\section{The New Zealand Free Kindergarten Service}

The struggle by women for women and children forms a significant part of the history of the kindergarten service. This struggle has been carried out from the beginnings of the kindergarten movement when the "well-to-do ladies" of society not only founded the kindergartens but continued to fundraise, support and promulgate the service for many decades. This work was not for themselves or their own children, but for the "needy children" and families of New Zealand. It was believed that the power of early education and care provided by the free 
kindergarten would shape the child for good moral living, and thus build a better society for the future. The initial intention was for provision of free kindergartens by well-to-do "patrons" for the so-called "needy" families, but as the worth and value of the service became more widely recognised, communities began to take responsibility for establishing, funding and maintaining kindergartens for their own children (Dempster, 1986). This struggle for provision, funding and ongoing maintenance of early childhood services was the work of women struggling against the status quo, arguing against injustices towards children and women, and challenging neglect by those in power and decision-making positions (May, 1990a; May, 1990b; May, 1993; Meade, 1990; Stonehouse, 1989; Wells, 1991).

As MacNaughton (1996) highlights:

It is hard to connect images of struggle, conflict and oppression with the "nice ladies of early childhood". Yet there has been considerable struggle and conflict in the early childhood field over many issues of policy and practice. (p. 1)

This struggle has addressed many issues and involved a great deal of opposition over the 107 years the free kindergarten service has been in existence. Funding to maintain provision of the free kindergarten has continually been a major concern. ${ }^{2}$ Over time, the worth of a child's early years and the value of early childhood education experiences have been established (Davis \& Thornburg, 1994; Podmore \& Swann, 1995). Despite this, the fight to retain a freely accessible kindergarten service continues and is as relevant today as it was in the $1880 \mathrm{~s}$

\section{Kindergarten Teachers and Employment}

The first New Zealand free kindergarten teachers were young women who worked as volunteers in a philanthropic way in kindergartens. They were predominantly from middle-class families who could support them, not only through their training, but also while teaching (Heslop, 1990, p. 18). It was not until 1948 that the state began paying kindergarten teachers' salaries (Heslop, 1990, p. 18). This was within a climate of growing acceptance of the educational value of sessional early childhood experience for young children - one which complemented, not substituted for, the family setting (May, 1990, pp. 99-101).

Then and now, union involvement and representation has played a significant role in kindergarten teachers' professional lives. The New Zealand Free Kindergarten Teachers Association (NZFKTA), established in 1952 as a professional and service organisation for kindergarten teachers, began this process. A significant milestone was reached in 1958 when the association received formal recognition allowing direct access to the Minister of Education for the first time, and so enabling salary claims to be lodged (Clark et al., 1983, p. 17). The 1960s saw a decade of rapid growth within the kindergarten services, raising issues that are still relevant today, issues which form much of the work of the present union, the New Zealand Educational Institute: Te Riu Roa (NZEI Te Riu Roa). ${ }^{3}$ These include "salaries and conditions of employment, professional status and the training of kindergarten teachers, roll numbers and children with special needs" (Clark et al., 1983, p. 17).

In an article reviewing the history of NZFKTA, Simpson (1993) describes the early 1970 s as a time of change for kindergarten teachers. She argues that during this time, kindergarten teachers were mainly young single women with non-political goals, focusing on training ( $\mathrm{p}$. 345). During the 1970s the organisation became more political in an attempt to improve the status of the kindergarten profession. Rosslyn Noonan joined the organisation as general secretary in 1976 and her commitment to women and children and the professional skills which she brought to the position "made the next five years a time of growth and gain for the association" (Simpson, 1993, p. 346).

The 1980s saw teachers continue to struggle to improve basic conditions and to regain lost ground after two and a half years of a government "wage freeze", which was eventually lifted in November, 1984 (K.T.A. News, Dec 1984, p. 5). A major salary claim was lodged with the Government in 1985 in an effort to attract into kindergarten teaching "skilled people [and a] cross-section of people who are representative of our society" (K.T.A. News, July 1985, p. 1). The NZFKTA also identified the urgent need to stop experienced teachers from leaving the service and to this end sought to address the issue of pay relativity with primary teachers. For the first time kindergarten teachers took nationwide ind ustrial action over this claim, holding stop work meetings both in, and outside of, contact session times, thus indicating the strength and depth of feeling over the inequitable salary positions (K.T.A. News, 1985). The catch cries of this campaign were "Kindergarten Teachers need more Dough" and "Crime Doesn't Pay and neither does Kindergarten Teaching". This was a significant development as it was the first time kindergarten teachers had taken industrial action over matters affecting pay and working conditions. Although not taken lightly, industrial action was used again throughout 
the later 1980s to make strong statements about later salary claims, and again in the early 1990s over other proposed Government policies (for example, the Employment Contracts Act).

Kindergarten teachers and employers, as state sector members (under the State Sector Act), have long been subject to all the state sector regulations and conditions of employment (Wells, 1991, p. 119). ${ }^{4}$ This has led to kindergartens having a distinctly different position from that of the rest of the early childhood sector. However, despite the status of kindergarten teachers as part of the state sector, their calls for relativity within the education sector have not been heeded. Kindergarten salaries remain significantly below those of the rest of the education sector. Small children are often not deemed to be "worth" much, despite numerous claims about the importance of the early years of life for a child. This is reflected in education pay structures, whereby the amount a teacher is paid increases with the age of the child being taught (Mitchell, 1993, p. 6). Kindergarten teachers have similar qualifications to those of their professional colleagues in the primary service, yet they continue to receive less remuneration, as Tables 1 and 2 show.

Table 1 Comparative Salaries of Teachers in the Kindergarten and the Primary Services in New Zealand

\begin{tabular}{|c|c|c|c|c|}
\hline \multirow[b]{2}{*}{ Annual Salary } & \multicolumn{2}{|c|}{ Kindergarten Teacher } & \multicolumn{2}{|c|}{ Primary Teacher } \\
\hline & 1995 & 1997 & 1995 & 1997 \\
\hline \multicolumn{5}{|l|}{ Starting salary: } \\
\hline Diploma only & 20,872 & 22,202 & 23,000 & 23,000 \\
\hline Diploma + degree & 23,683 & 24,986 & 26,000 & $26,000 *$ \\
\hline \multicolumn{5}{|l|}{ Maximum: } \\
\hline Diploma only & 28,158 & 29,707 & 34,380 & 36,103 \\
\hline Diploma + degree & 31,142 & 32,855 & 38,545 & 41,860 \\
\hline
\end{tabular}

* By 1997 qualification groups for the primary service will be redefined and the starting salary for a teacher with a four or five year degree will be higher. For this example these differences have been excluded.
Table 2 Comparative Salaries of Head Teachers in the Kindergarten and the Primary Services in New Zealand

\begin{tabular}{|c|c|c|c|c|}
\hline \multirow{2}{*}{ Annual Salary } & \multicolumn{2}{|c|}{ Kindergarten Head Teacher } & \multicolumn{2}{|c|}{ Primary G1 Principa } \\
\hline & 1995 & 1997 & 1995 & 1997 \\
\hline \multicolumn{5}{|l|}{ Starting salary: } \\
\hline Diploma only & 29,504 & 31,127 & 36,780 & 40,500 \\
\hline Diploma + degree & 32,486 & 34,273 & 40,269 & 45,000 \\
\hline \multicolumn{5}{|l|}{ Maximum: } \\
\hline Diploma only & 32,486 & 34,273 & 40,967 & 48,000 \\
\hline Diploma + degree & 35,471 & 37,422 & 44,908 & 48,000 \\
\hline
\end{tabular}

* A G1 principal is usually a sole charge teacher responsible for up to 29 children, or a teaching principal of a two-teacher school with up to 58 children.

A kindergarten head teacher may have one other teacher to assist, and up to 60 children ( 2 sessions of up to 30 children per session) or two other teachers and up to 90 children ( 2 sessions of up to 45 children).

There can be variations to these arrangements.

(Sources for both tables: NZEI Te Riu Roa (1995a), Primary Teachers' Collective Employment Contract 1995 to 1998; NZEI Te Riu Roa (1995b), Kindergarten Teachers' Collective Employment Contract, and NZEI Te Riu Roa (1996g), Union Ratification Meeting notes.)

Kindergarten, primary and secondary teachers began the 1991 employment negotiations in an allied approach resulting in an employment award package ${ }^{5}$ which was jointly settled in 1991. A formal agreement was put in place by 30 April, before the Employment Contracts Bill became law. This provided protection for teachers for another twelve months, but left the existing pay and conditions intact under a new collective employment contract. While this gave twelve months grace, it also meant another twelve months with no improvement to salary and working conditions.

The year 1992 saw the kindergarten service (along with the other education sectors) negotiate its first contract under the new terms of the Employment Contracts Act and within the new arrangements since the introduction of bulk funding. ${ }^{6}$ The interim Collective Employment Contract of all education sector unions expired on the 31st of July 1992. 
Despite an attempt to take a sector-wide approach to salary negotiations, the State Service Commission and employers made it clear at the outset that the times had indeed changed since the 1991 roll-over, and insisted that each education sector be negotiated separately. Each expired award, and its contents, ceased to exist, and every employment condition had to be re-negotiated into the new contract - nothing was automatically included.

The 1992 contract negotiations were protracted over seven months. The settlement left the teachers with a clear understanding that the climate for negotiating had indeed changed and a more politicised activism would be needed to regain lost ground and lost conditions. The 1992 settlement maintained teachers' existing pay rates, with no improvements but no losses for permanently employed staff. Kindergarten relievers received the harshest settlement, with pay rates capped at a new daily amount and some allowances removed or substantially altered. For all permanent teachers an "hours of work" clause was introduced which gave employers new discretionary rights to call teachers to work in times which had previously been seen as "holidays". Statutory holidays were the only holidays specified in the contract. ${ }^{7}$ Substantial changes were made to sick leave entitlements, maternity grant payments and other allowances. When the contract was finally ratified, most kindergarten teachers were relieved at the number of conditions which had been retained. However, with some lost conditions and a nil wage increase, the scene was set for 1994 where teachers and the Combined Early Childhood Union of Aotearoa (CECUA) hoped to secure a pay increase and prevent the loss of any more existing conditions.

By 1994, when the next employment contract was due to be negotiated, there were severe recruitment and retention problems within the kindergarten service. Nationally 35 percent of all positions were advertised (NZEI Te Riu Roa, 1995c). Kindergartens were struggling to survive on funding rates that were based on 1991 expenditure figures, and some kindergarten associations had huge budget deficits. The Dunedin Kindergarten, for example, was facing a deficit of $\$ 90,000$ by the end of 1995 and insolvency in 1996 (Dunedin Kindergarten Association, 1995). It became clear that kindergartens nationally were in a funding crisis.

At this time it again became readily apparent to teachers, parents and association members alike that political activism was going to be needed to protect and maintain the free kindergarten service. While bodies such as the kindergarten associations and teacher unions had historically been set up to act as support and lobby groups, teachers and parents alike realised that these organisations by themselves could not take total responsibility to represent the best interests of children or the service. Women joined together to tackle the issues they felt were injustices. Two examples from Dunedin demonstrate the passion and politicisation that these "nice ladies" of early childhood entered into "for the sake of the kindergarten service". ${ }^{8}$

\section{First example}

In April 1995 a group of kindergarten parents representing many of the Dunedin kindergartens met to discuss their concerns over a likely Dunedin Kindergarten Association deficit, and to brainstorm ways of supporting the teachers in ensuring kindergartens remained open and retained their existing unique philosophy. The group proposed a public meeting to make known the plight of the kindergartens and the Dunedin Association (Dunedin Kindergarten Association, 1995). Working alongside teachers, the group organised a public meeting on 25 June in Dunedin. Approximately 400 people attended the meeting, including teachers, parents, educationalists, and representatives from the Dunedin Association and political parties. The publicity surrounding the meeting raised the funding issues clearly in the minds of the Dunedin public and resulted in national media coverage (National Radio, Insight 2 July, 1995).

\section{Second example}

Dunedin kindergarten teachers (along with others) were very concerned over the eventual 1995 employment contract settlement. The changes to their employment conditions, offset by a small 2 percent pay increase, left teachers feeling dissatisfied not only with the settlement but with those who had represented them in that settlement. ${ }^{9}$ The particular issue of concern centred around the increase in the number of teaching sessions per year and a specification of an entitlement of 5 weeks annual leave. By being expected to work more sessions, the teachers felt that they were then working to pay for their own wage increase. The advantage of having annual leave specified in the employment contract for teachers was that, without this, employers could insist on their teachers working all but the minimum three weeks (plus statutory days) as set out in legislation. Dunedin kindergarten teachers believed that based on "custom and practice" teachers were 
entitled to 12 weeks annual leave. They sought legal advice from a lawyer specialising in employment contracts. The resultant advice did not support the union's position. ${ }^{10}$ When presented with the employment contract to ratify, Dunedin teachers voted 56-0 against ratification. Concerned that this action by itself would not be enough to stall the contract settlement, Dunedin teachers personally contacted as many other kindergarten teachers as possible throughout New Zealand, encouraging them to vote against the settlement and thus motivate NZEI Te Riu Roa to further investigate the leave provisions. This was a particularly significant action for kindergarten teachers - demonstrating changing feelings towards their union representation. Striking or taking militant action of any kind has never been taken lightly by teachers, as the conflicting discourses of caring for children versus taking action on their own behalf have always been a source of tension for teachers. ${ }^{11}$ This action was therefore unprecedented, as it was targeted not at the government or employers, but at the union which represented the teachers. Despite this action, the contract was nationally ratified for a nine month term ending in November 1995 as an interim measure (NZEI Te Riu Roa, 1996a). In response to this, Dunedin members passed a vote of no confidence in NZEI Te Riu Roa (Landreth, personal communication, April 20, 1995).

\section{Budget and Funding}

In the 1995 budget the additional available funding for the kindergarten service was minimal. ${ }^{12}$ At the same time, the government paved the way for increased hours of work for teachers by removing the cap on the number of funded sessions kindergarten associations could operate. While this offered the potential for generating increased revenue, it was seen as yet another threat to teachers' working conditions. By proposing to reduce teachers' noncontact and "term break" times, it had the potential to undermine the quality of early childhood education for children by removing, or at least eroding, the time teachers use for planning, meeting with parents and all the other tasks necessary to maintain a quality learning environment.

In response to the perceived inadequacy of funding for kindergartens, a united group comprising teachers, NZEI Te Riu Roa, kindergarten associations and parents launched a sustained combined national funding campaign in an attempt to increase government funds to realistic funding levels so as to maintain a free and accessible early childhood education for all. This included intensive lobbying of MPs, national media coverage, circulation of a national petition, a national day of action, culminating in a three day hearing by the Parliamentary Science and Education Select Committee. The Committee recommended to the government that favourable consideration be given to an increase in kindergarten funding. In November 1995 once again the kindergarten employment contract expired.

\section{6 - Women's Work, Women's Worth and the Women's Vote}

The political climate in 1996 was very different from that in any other year in which teachers had been negotiating their employment conditions and pressing for increased funding for the early childhood service. The scene had been set: the combined funding campaign for accessible early childhood education continued; there was support from the Science and Education Select Committee for increased funding for kindergartens; it was an election year; and, significantly, it was the first MMP election for New Zealand. Politicians began to listen to their electorates, as the women's vote was seen as one to be "courted". In the past the calls to have women's work "count for something" had been widely ignored, and calls for recognition of women's work had been seen to produce contradictory outcomes. ${ }^{13}$ The new political climate of 1996 meant that in both the funding campaign and the employment campaign the call for women's work to be adequately funded and supported began to be picked up not only in the media, but by opposition MPs and "hopeful" politicians. The outcomes were positive. On Thursday afternoon (20 June, 1996), Trevor Mallard, MP for Pencarrow and Labour's associate spokesperson for education, pressed the Prime Minister in the following exchange:

Trevor Mallard: Rephrasing my earlier question, I ask the Prime Minister whether, when the New Zealand Educational Institute and the State Services Commission reach an agreement as to the rate of pay increase, the Government will then provide the additional funding by way of supplementary estimates to cover that?

Rt Hon. J B Bolger: As in all the negotiations that the State Services Commission conducts, if it reaches an agreement that is consistent with the Government's policy, then of course we pay the money. (NZEI Te Riu Roa, 1996b) 
NZEI Te Riu Roa saw the Prime Minister's response as positive. The lack of government funding had been perceived as the main stumbling block. Now the challenge was to turn the Prime Minister's words into action (NZEI Te Riu Roa, 1996b).

As the year continued, teachers came no closer to a contract settlement. Despite the recommendations from the Science and Education Select Committee, additional funding in the budget was again minimal $(2.5 \%)$; the service was facing its worst staff recruitment and retention problem ever; ${ }^{14}$ and the pressure was on for teachers to work additional sessions so kindergartens could continue to operate.

"The teachers face a Hobson's choice. They must either work much longer hours or accept a tiny funding increase which goes no way to rectifying the erosion of their pay since 1990", said Ms Slowley, an NZEI Te Rui Roa spokesperson. "The kindergarten service was very fragile, and had only survived the past five years because teachers worked longer hours with larger groups.... There is no way teachers will be persuaded to pay for their own pay increases by teaching more sessions" (Staff Reporter, 1996b).

The teachers became more vocal, directly challenging the National government policies in an attempt to emphasise the issues for the public. Kindergarten teachers had decided "we' ve got to put our foot down somewhere and this could be it" (Staff Reporter, 1996d). Media releases, newsletters and radio interviews expressed the outrage over the government's treatment and lack of support for women, and women in the kindergarten service, users and providers alike.

The government's treatment of kindergartens and kindergarten teachers is absolutely disgusting. Kindergartens provide a service that is largely staffed by women, supported by women through hours of voluntary work, set up by women and used by women. The government's failure to provide a justified pay increase for teachers and an unconditional funding increase for

kindergarten sends a strong signal to the public of the contempt in which it holds women. (NZEI Te Riu Roa, 1996d)

Although the government had now settled the other education employment contracts (primary and secondary), kindergarten teachers were offered a nil wage increase in June. They were outraged. The link between kindergarten teachers as a group of women workers and the nil wage offer could not be ignored. NZEI Te Riu Roa National Secretary Rosslyn Noonan said the union viewed the nil wage offer as
"... absolutely disgusting. I'm actually quite shocked by the contempt the Government is showing for this group of really dedicated, committed women workers" (Staff Reporter, 1996c). She compared the kindergarten negotiations with the recently settled secondary teachers' pay claim. "The Government had emerged from the recent bitter dispute over secondary teachers' pay saying it wanted a more constructive way of negotiating," Ms Noonan said, "... yet its actions in the kindergarten teachers' talks hardly showed a constructive attitude. It seems to me that the Government is sending out a strong message that the only thing it respects is very strident and macho action and I think that's pretty disturbing" (Staff Reporter, 1996c).

Hopeful that in this time of political change some improvement might indeed have been possible, in the face of government rhetoric, kindergarten teachers, parents, NZEI Te Riu Roa and kindergarten association members maintained support for both the funding campaign and the contract negotiations.

Kindergarten teachers have made an enormous impact. There is huge support from parents and the community, the politicians are feeling the pressure and many, including government MPs, have publicly stated their support. Government ministers are clearly interested in resolving the funding issue. Cabinet continues to meet, the election is looming. All these factors, place us in a strong position and we must keep campaigning. (NZEI Te Riu Roa, 1996f)

Through the combined energy of the teachers, parents, NZEI Te Riu Roa and kindergarten associations (predominantly women), the effects of this activism became noticeable with shifts in government funding policy occurring not once but three times in 1996.

1. 1996 Budget announcement: Funding increased to $\$ 2.9725$ per child per hour (an increase from \$2.90), effective from 1 January, 1997 (NZEI Te Riu Roa 1996e);

2. July Package: Two options presented: a) Maximum of 320 sessions to be retained and funded at a new rate of $\$ 2.9725$ per child per hour; or b) the existing rate of $\$ 2.90$ per child per hour to be retained, with lifting of cap on funded sessions from 320 to 360 per year, effective from 1 January, 1997 (English, 1996c);

3. September Agreement: Hourly rate to be increased unconditionally from $\$ 2.90$ to $\$ 3.09$ per child per hour; however the cap of 360 sessions to 
remain as government policy (effective from January 1 1997). (English, 1996a)

While the very successful funding campaign had been targeted at ensuring that the government would supply adequate finance for the kindergarten service to continue to operate, it proved difficult to separate this outcome from the kindergarten teachers' own employment contracts negotiations. One directly affected the other. Indeed, the teachers often came under attack for "self interest and political manipulation" as the two campaigns became conflated in the minds of commentators in the media. ${ }^{15}$

Associate Education Minister Bill English said today [4 October, 1996] he was sorry some kindergarten teachers had decided to strike for a second time and questioned their commitment to resolving the pay dispute.

Last week the Government agreed to a significant increase in funding for kindergartens....The associations and the Government believed this would provide the room to move to find a settlement....At this stage of the dispute it is difficult not to believe that this strike is politically motivated for the week running up to the election. It is in everyone's interests to settle this claim. Hopefully that can happen after the election when there are less political pressures at work. At the end of the day it's the children who suffer and that is the big pity of this situation." (English, 1996b)

Four days from the election (held on 12 October), an employment contract settlement offer was received by the union from the government. Strike action which had been planned for election week to highlight the issues for those heading to the voting polls was called off. "The government's eleventh hour $\$ 7$ million pay offer to kindergarten teachers shows it is finally taking account of the issues important to women", said the NZEI Te Riu Roa National Secretary, Rosslyn Noonan. "While the offer was 'not ideal', it was significant enough to be put to members to vote on.... It shows the government is finally waking up to the fact that the way they are treating kindergarten teachers has ramifications on how women view the government" (Staff Reporter, 1996a).

While this settlement occurred at a politically expedient time for the Government it contained conditions that could be seen as gained "against all odds". Not only did the settlement include an increase of
5.5 percent across the salary rates (from January 1997) and a one-off immediate payment for teachers, but it also included new and improved employment conditions - redeployment and redundancy provisions, improved maternity leave and maternity grant. Importantly, it also contained a commitment to a job evaluation which is the first step to consideration for pay parity and relativity within the wider education sector. The significance of these provisions cannot be overestimated in a "flexible labour market". Since the introduction of the Employment Contracts Act, the devolution of decision making in schools (1988), and bulk funding in early childhood (1992), commentators have argued that this flexibility may provide advantages for the employer, but means "quite a different thing for teachers, especially those who are women" (Court, 1994, p. 111). Working conditions which are particularly significant for women have often been the first to be cut - maternity grants, and additional leave for family reasons, for example. Travers (1989) was concerned that women teachers would be forced to fight all over again to win rights such as maternity leave provisions, permanent part-time work, domestic leave (for caring for family members), and preference to get a job back after childcare leave (Travers, 1989, p. 36, cited in Court, 1994, p. 86)

Kindergarten teachers had experienced just this struggle, losing much ground in what could be argued as essential employment conditions for women since 1992, and regaining some of what they had lost, as well as improvements in new conditions in 1996. These gains can be seen in terms of political expedience. For once, being a women's occupation had procured positive outcomes, "against all odds", for the kindergarten teachers, largely because this was a time when the Government wished to capture the voting public. Alongside this, the continuing belief in the worth of the kindergarten service for children and families, and thus the worth of those who work with and for the children - the teachers - has provided a powerful discourse. Women once again have united together, as they have historically done in early childhood education, to challenge dominant views which continue to undermine women's work and denigrate the value of early childhood provisions.

\section{Conclusion}

The 1990s have been a time of political change and turmoil for the early childhood sector. As in the depression years of the 1880s when women combined together to fund, support and promulgate a free kindergarten 
service for New Zealand's children, the political activism, energy and positive belief in women and women's work has driven early childhood education since the 1880s. As the call for recognition for women's needs and women's work was politically expedient in 1996 (the first MMP election year), teachers were able to regain lost ground in terms of employment conditions, "against the odds". The combined work of all those interested in the kindergarten service was able to influence the funding policies for the service, and the movement bought some "more time" for the kindergartens to continue to operate under their traditional philosophies. The challenges ahead will not be easy now the election is over. The campaign for a free and accessible early childhood education for all will continue as the inequities of early childhood provisions and access remain a reality. For kindergarten teachers the prospect of a job evaluation will be the first step in addressing the issues of relativity with their teaching colleagues.

\section{Notes}

1. This first verse of the song "Don't Be Too Polite Girls" was reproduced in the Women's Subcommittee Choir of the Wellington Trades Council Song Book from the Builders Labourers' Song book. Since the start of the choir in 1979 it has been their theme song, and the most popular.

2. While the term "free" is generally used to indicate that all children may attend irrespective of race, gender, creed, ethnicity, class, etc., it is also used here to mean literally "free", i.e., involving no form of compulsory payment.

3. Kindergarten teachers have been represented by the New Zealand Free Kindergarten Teachers Association (NZFKTA) from 1952-1989. Amalgamation of the NZFKTA with the Early Childhood Workers Union (ECWU) formed the Combined Early Childhood Union of Aotearoa (CECUA) 1990-1994. CECUA then amalgamated with the New Zealand Education Institute Te Riu Roa, which now currently represents early childhood interests as well as those of primary teachers and various other education support staff.

4. As part of the state sector, kindergarten teachers are state sector employees, but their direct employers, under recent legislation, are the individual kindergarten associations.

5. National awards were the employment documents before the Employment Contracts Act.

6. For a full discussion of bulk funding and changes to the funding for the kindergarten service see Duncan (1994a); Wylie (1992) and Wylie (1993).

7. Other annual leave was specified in legislation such as the Holidays Act.

8. These examples are chosen as they are known to the authors. They are just two examples of the many campaigns, activities and initiatives which were happening nationwide at the same time.

9. The increase was 2.5 percent for teachers and 3.5 percent for head teachers.

10. A similar case had been previously argued and defeated at the Auckland Employment Tribunal in 1994. Teachers thought it important to define leave entitlement in such a way as to protect it with an explicit contract provision.

11. For further discussion on the contradictory discourses of kindergarten teachers with regards to union activism, see Duncan (1994a \& b), and Duncan (1996).

12. This increase was less than 1 percent $(0.87 \%), \$ 2.90$ per hour per child, and was inaccessible until 1 March 1996.

13. For further discussion see Duncan (1996) and Farquhar (1995).

14. Nationally, 45 percent of vacancies were advertised in 1996, with 60 percent in Auckland (Staff Reporter, 1996c).

15. See Duncan (1996) for further discussion on how claims of teacher self-interest were used against kindergarten teachers arguing for the interests of the children and the kindergarten service.

\section{References}

Apple, M. (1986). Teachers and Texts. New York: Routledge and Kegan Paul.

Casey, K., \& Apple, M. (1989). Gender and the conditions of teachers' work: The development of understanding in America. In S. Acker (Ed.), Teachers, gender and careers (pp. 171-202). New York: Routledge and Kegan Paul.

Clark, K., Cook, H., \& Pearson, J. (1983). Two models of unionism in early childhood education. Paper presented at the Third Early Childhood Convention, Ngaruawahia, New Zealand.

Cook, H. (1983, October). Early childhood education: A woman's sphere in a man's world. New Zealand Monthly Review, 259, 14-15.

Cook, H. (1985). Myths, realities and dreams of early childhood services. Paper presented at the Early Childhood Forum, Parliament Buildings, Wellington. 
Court, M. (1994). 1893-1993: How far have we come in women's employment in education? New Zealand Annual Review of Education, 3, 81-128.

Dalli, C., \& Meade, A. (1991). Review of the early childhood sector in New Zealand. New Zealand Annual Review of Education, 1, 113-132.

Davis, N. S., \& Thornburg, K. R. (1994). Child care: A synthesis of research. Early Child Development and Care, 98, 39-45.

Dempster, D. (1986). From patronage to parent participation - the development of the Dunedin Free Kindergarten Association 1889-1939. Unpublished Diploma of Education thesis, University of Otago, Dunedin.

Duncan, J. (1994a). The national New Zealand Kindergarten Teachers collective employment contract negotiations of 1992. One paper research study, Postgraduate Diploma in Arts, University of Otago, Dunedin.

Duncan, J. (1994b). The national New Zealand Kindergarten Teachers collective employment contract negotiations of 1992. Paper presented at the New Zealand Association for Research in Education Conference, Christchurch.

Duncan, J. (1996). "For the sake of the children" as the worth of the teacher? The gendered discourses of the New Zealand National Kindergarten Teachers' employment negotiations. Gender and Education, 8(2), 159-170.

Dunedin Kindergarten Association. (1995). 1995 Annual report and budget proposal. Dunedin: Dunedin Kindergarten Association.

Dunn, A., Pole, N., \& Rouse, J. (1992). The education sector workforce: Te pewanga whakaakaranga o te hunga whaimahi. Wellington: Ministry of Education.

English, B. (1996a). Kindergarten agreement reached. Media release. Wellington: Office of the Minister of Education.

English, B. (1996b). Reaction to kindergarten strike. Media Release. Wellington: Office of the Minister of Education

English, B. H. (1996c). Speech to New Zealand Free Kindergarten Association Annual Conference. Wellington: Office of the Minister of Education.

Farquhar, S.-E. (1995). Qualifications, gender and income: Inter-related issues in the early education sector. New Zealand Annual Review of Education, 4, 39-55.

Heslop, J. J. (1990). Early childhood care and education as social control: An examination of the kindergarten training curriculum in Auckland between
1910-1990. Unpublished thesis, Master of Philosophy in Education, University of Auckland.

Lauder, H., Middleton, S., Boston, J., \& Wylie, C. (1988). The third wave: A critique of the New Zealand Treasury's report on education. New Zealand Journal of Educational Studies, 23 (1), 15-35.

Lauder,H.(1991). Tomorrow's education, tomorrow's economy. Wellington: New Zealand Council of Trade Unions.

MacNaughton, G. (1996). Collaborating for curriculum change in postmodern times: Some ethical considerations. In Weaving Webs: Collaborative Teaching and Learning in the Early Years Curriculum. The University of Melbourne: Department of Early Childhood Studies.

May, H. (1985). Mind that child: Childcare as a social and political issue in New Zealand. Wellington: Blackberry Press.

May, H. (1990a). Growth and change in the early childhood services: A story of political conservatism, growth and constraint. In S. Middleton, J. Codd, \& A. Jones (Eds.), New Zealand education policy today (pp. 94-109). Wellington: Allen and Unwin.

May, H. (1990b). From a floor to a drawer - a story of administrative upheaval: A post Meade reflection on early childhood policy. In Second Research into Education Policy Conference. Wellington: New Zealand Council for Educational Research.

May, H. (1992). After "Before Five": The politics of early childhood care and education in the nineties. Women's Studies Journal [New Zealand], 8(2), 83-100.

May, H. (1993). When women's rights have come to stay Oh who will rock the cradle? Hamilton: Department of Early Childhood, Waikato University.

Meade, A. (1990). Women and young children gain a foot in the door. Women's Studies Journal [New Zealand], 6(1-2), 96-110.

Ministry of Education (1992). An overview of equal employment opportunities in the teaching service. Wellington: Ministry of Education.

Ministry of Education (1992b). Early childhood education provision in New Zealand: A summary of recent trends. New Zealand Education Gazette, 71(21), 1-3.

Mitchell, L. (1993). Back against the wall. Staff and the quality of early childhood education: The impact of government policy. In What is the government's role in early childhood education. Wellington: New Zealand Council for Educational Research. 
Mitchell, L. (1996). Crossroads - Early childhood education in the mid-1990s. New Zealand Annual Review of Education, 5, 75-92.

National Radio. (1995). Kindergartens in crisis. Insight, 2 July. Wellington: New Zealand On Air.

New Zealand Free Kindergarten Teachers Association (1984-1990). KTA News.

NZEI Te Riu Roa. (1995a). Primary teachers' collective employment contract 1995 to 1998. Wellington: NZEI Te Riu Roa.

NZEI Te Riu Roa. (1995b). Kindergarten teachers' collective employment contract. Wellington: NZEI Te Riu Roa.

NZEI Te Riu Roa (1995c). Submission to the Education and Science Select Committee Funding for Kindergartens. Wellington: NZEI Te Riu Roa.

NZEI Te Riu Roa. (1996a). Contracts ‘96. (27). Wellington: NZEI Te Riu Roa.

NZEI Te Riu Roa. (1996b). Contracts ‘96. (28). Wellington: NZEI Te Riu Roa.

NZEI Te Riu Roa. (1996c). Contracts ‘96. (31).Wellington: NZEI Te Riu Roa.

NZEI Te Riu Roa. (1996d). Speech notes for Kindergarten Strike Day 3 September. Wellington: NZEI Te Riu Roa.

NZEI Te Riu Roa. (1996e). Contracts update, 22 May. Wellington: NZEI Te Riu Roa.

NZEI Te Riu Roa. (1996f). Contracts update, 12 September. Wellington: NZEI Te Riu Roa.

NZEI Te Riu Roa. (1996g). Union Ratification Meeting. Wellington: NZEI Te Riu Roa.

Peters, M., \& Marshall, J. (1990). Children of Rogernomics: The New Right, individualism and the culture of narcissism. Sites, 21(Spring), 174-191.

Podmore, V. N. \& Swann, F. (Eds.). (1995). Early years - Research: Papers from NZCER seminars on early childhood. Wellington: New Zealand Council for Educational Research.

Sayers, J. (1992). Women and the Trade Union Movement. In S. Olsson (Ed.), The gender factor: Women in New Zealand organisations (pp. 226-239). Palmerston North: Dunmore Press.

Simpson, J. (1993). New Zealand Free Kindergarten Teachers' Association 1954-1990. In A. Else (Ed.), Women together: A history of women's organisations in New Zealand (pp. 345-347). Wellington: Historical Branch Department of Internal Affairs, Daphne Brasell Associates Press.
Simpson, T. (1993). The Employment Contracts Act in the state sector. In R. Harbridge (Ed.), Employment contracts: New Zealand experiences (pp. 134-147). Wellington: Victoria University Press.

Staff Reporter. (1996a, 11-17th October, 1996). Deal averts strike. New Zealand Education Review, p. 9.

Staff Reporter. (1996b, 29 July 1996). Extra kindergarten funding. Otago Daily Times.

Staff Reporter. (1996c, 27 June, 1996). Govt pay offer appals kindergarten union. Otago Daily Times.

Staff Reporter. (1996d, 5 August, 1996). Pay claim to be reviewed. Otago Daily Times.

Stonehouse, A. (1989). Nice ladies who love children: the status of the early childhood professional in society. Early Child Development and Care, 52, 61-79.

Travers, A. (1989). The State Sector Act and Tomorrow's Schools: Implications for women. Delta, 41, 33-39. Cited in Court, M. (1994). 1893-1993: How far have we come in women's employment in education? New Zealand Annual Review of Education, 3, 81-128.

Wells, C. (1991). The impact of change - against the odds. In M. Gold, L. Foote, \& A. B. Smith (Eds.), Fifth Early Childhood Convention, (pp. 115-127). Dunedin, New Zealand: Fifth Early Childhood Convention.

Women's Subcommittee Choir of the Wellington Trades Council Song Book. (n.d.). Wellington:Women's Subcommittee Choir of the Wellington Trades Council.

Wylie, C. (1992). First impressions: The initial impact of salary bulk funding on New Zealand kindergartens. Wellington: New Zealand Council for Educational Research.

Wylie, C. (1993). The impact of salary bulk funding on New Zealand kindergartens. Wellington: New Zealand Council for Educational Research.

\section{Acknowledgments}

We wish to thank Dr Peter Rich, University of Otago, for his support and comments on this paper. We also salute the ongoing work of the Early Childhood Caucus of NZEI Te Riu Roa, and the Kindergarten Contract Negotiation Teams (past and present). 
The authors

Judith Duncan is at present a lecturer and doctoral student with the Education Department, University of Otago. She teaches and researches in the area of politics and policy in early childhood education. Judith's doctoral research is based on life history interviews with New Zealand kindergarten teachers as they reflect on both their personal and professional experiences. She has recently published work examining the 1992 Kindergarten Teachers' National Collective Employment Negotiations.

Lee Rowe is a kindergarten teacher actively involved in industrial and professional issues affecting kindergarten teachers. She is the Otago representative for NZEI Te Riu Roa Early Childhood National Caucus. Lee is currently employed at Dunedin College of Education as co-ordinator for a Ministry of Education contract implementing Te Whāriki in centres and services throughout Otago and Southland. 